hampton he came to take charge of the Operations Section of the Air Department, Admiralty, but only remained there for a few months as his health would not stand unaccustomed office work. In the autumn of 1916 he was appointed commanding officer to commission Pulham, the first rigid airship station to be completed in this country. He was recalled from there to the Admiralty again in June, 1917, to take up the responsible duties of Captain Superintendent, Lighter than Air, in the Air Department. In November, I917, he assumed the title of Superintendent of Airships when the Airship Section of the Air Department became the Airship Department, Admiralty, on the transfer of aeroplanes and seaplanes to the Air Board. This position he held until the signing of the Armistice, and for some time thereafter, and it was almost entirely due to the effect of his personality that the Board of Admiralty embarked upon a greatly increased programme of airship construction, which included twelve rigid airships and a large number of the non-rigid type. When airships were transferred to the Air Ministry at the end of rgrg he went to Kingsway in a somewhat indefinite appointment to assist in fitting the various portions of the Airship Department into the appropriate departments of the Air Ministry organisation. At the time of his death he was Commanding Officer of Howden Airship Base.

Though it is not possible to detail his many parachute descents here, it must not be forgotten that during all the period from 1916 onwards he took any and every opportunity of jumping off in a parachute from every type of aircraftballoon, kite-balloon, airship and aeroplane-for no other reason than to give others a lead and prove to the authorities and the public that the parachute offers a means of saving life in case of accident. In view of this it is peculiarly significant that when found after the accident to $R_{3} 8$ he was shown to have devoted his last moments to an endeavour to check the fall of the airship rather than to saving his life by means of a parachute.

It is impossible to write adequately of Maitland's personal charm of appearance, voice and character. Everyone who met him received the impression -which every action of his did nothing but confirm-of absolute honesty of purpose, combined with an unflinching devotion to the cause of airships. He imbued those who served with him with a sense of trust which was absolute, while the personal love which he inspired in all with whom he came in contact was truly wonderful. He had tact to a quite exceptional degree, and his manners recalled the courtly grace of a bygone age. To all those who knew him he will live as an unforgettable memory. He was a firm supporter of this Society, being elected as a Founder Member in April, I909, and made an Associate Fellow in I9r2. He served on the Council from March, IgI2, to November, I913. Many members will remember the delight which he gave to an audience of children, when he related his experiences during the Atlantic flight of $R_{34}$ at the Society's Annual Juvenile Lecture in January, I92 I, whilst his last opportunity of manifesting his interest in the Society was in very appropriately taking the chair on the occasion of Major Orde Lee's paper on "Parachutes" and Mr. Dyer's "Airship Fabrics" lecture on March 3 this year.

\title{
CONSTRUCTOR COMMANDER C. I. R. CAMPBELL, O.B.E., M.I.N.A., F.R.Aë.S., R.C.N.C.
}

Charles Ivor Rae Campbell was educated between the years I 894 and I 899 at the Royal Naval Engineering College, Devonport, where he obtained the Newman Memorial Prize for highest proficiency in engineering subjects. From there he went in I 899 to the Royal Naval College, Greenwich, where his career was remarkable, in that he followed the engineering course by taking also the course in design for constructors; thus obtaining very exceptional qualifications. for his future career. On leaving Greenwich he went to the Admiralty, where 
the remained until I908, engaged chiefly upon submarine design work. He was then appointed overseer for submarine hulls at Messrs. Vickers' Works at Barrowin-Furness, where he remained four years, during which period he laid the foundation of his future airship work through being able to watch the construction of Naval Airship No. I, the first British rigid airship, which was built at Barrow while he was there. From Barrow he was appointed, in 1913, Admiralty overseer at Messrs. Armstrong's works at Newcastle-on-Tyne for the construction of H.M.S. Malaya and various submarines, where he remained until December, I914, when he sailed for America as Admiralty overseer of the construction of submarines and M.L. boats in the United States. He also went to Canada, where he supervised the erection and testing of these boats before returning to England to undertake airship design work under Mr. A. W. Johns, in the Department of Naval Construction at the Admiralty, at the end of 1915; being immediately responsible for the work of the airship design staff then formed.

It was soon after this that he produced the design of the " ${ }_{2} \mathrm{X}$ " class of rigid airship. The design, of which only $\mathrm{R}_{27}$ and $\mathrm{R}_{29} 9$ were built, was approved in spite of considerable opposition owing to the absence of a structural keel, there being merely a corridor through the hull which was not a strength member. In 1917, on the reorganisation of airship work in the Admiralty, he assumed the primary responsibility for airship design by taking charge of the Design Section of the department of the Director of Production (Airships) under the Navy Controller. It was during this period that the design of $\mathrm{R}_{3} 8$, which incorporated many original features, was prepared. On leaving the Admiralty in 1920 for the Air Ministry, he became Superintendent of Airship Construction and Design at the Royal Airship Works, Cardington.

Campbell was unquestionably the most experienced and foremost airship designer in this country, and had, outside Germany, a unique knowledge of the problems of rigid airship design and construction. He had the fullest confidence in the future of airships, and was a firm believer in the importance of progressive increase in size. For the head of a department he assumed an unusual amount of personal responsibility for the work, and was never content to leave the smallest detail to others. He was always particularly anxious to study the results of his work in practical flight, and had been on all the trial flights of $R_{3} 8$, and had succeeded in obtaining the somewhat reluctant permission of his superiors to his embarking in the airship when she should leave for America.

$\mathrm{He}$ had done much proselytising work to arouse both technical and public interest in airships, among the lectures he gave being one before the Institute of Naval Architects on "The Development of Airship Construction," on April Ioth, I9I9. He was elected an Associate Fellow of the Society on March I6th, 1920, which was followed by his election to Fellowship on April Igth this year. On April 25th last, at the request of the Society, he read a Paper on "Airship Transport," at the Olympia Efficiency Exhibition.

FLIGHT LIEUTENANT J. E. M. PRITCHARD, O.B.E., A.F.C., F.G.S., A.F.R.Aë.S.

John Edward Maddock Pritchard was born at Leighton Buzzard in 1889 , and was of Welsh ancestry. He was educated privately and at Trinity College, Cambridge, whence he proceeded to the Royal School of Mining, South Kensington, where he graduated First Class in mining surveying. He then took up the career of a mining engineer, and was at one time engaged upon one of the most important mining surveys ever carried out in this country, having been elected a Fellow of the Geological Society of London some time previously. His interest in aeronautics was not confined to his war experience, as he had made several flights in the early days of aviation with, amongst others, the late S. F. Cody. 